\title{
Microbial Properties of Soil in Different Coverages in the Colombian Amazon
}

\author{
Lised Guaca Cruz ${ }^{1}$ (D), Amara Tatiana Contreras Bastidas ${ }^{1}$ (D), \\ Leonardo Rodríguez Suárez ${ }^{1}$ (D), Juan Carlos Suárez Salazar ${ }^{1}$ (i) \\ ${ }^{1}$ Universidad de la Amazonia, Florencia, Caquetá, Colombia
}

\begin{abstract}
Changes in coverage affect the activity of soil's microbial communities, affecting the carbon and nitrogen cycle. The variability of biochemical properties in different coverages (native forest, forest plantation, silvopastoral system and pasture) located in the northwest of the Colombian Amazon was evaluated. Edaphic properties were determined as: organic carbon (OC), total nitrogen (TN), microbial biomass carbon $(\mathrm{MBC})$ and microbial biomass nitrogen $(\mathrm{MBN})$ using the fumigation method. A significant effect was found to land use $\times$ depth interaction for the variables moisture, $\mathrm{pH}, \mathrm{CO}$ and $\mathrm{MBC} / \mathrm{OC}$ ratio $(p<0.05)$, while $\mathrm{MBC}$ and $\mathrm{dCO}_{2}$ showed differences only for land use and NT, MBN and MBN/TN ratio at depth $(p<0.05)$. In general, when modifying the soil cover, changes were made in the chemical properties that affected the microbial activity.
\end{abstract}

Keywords: fumigation, $\mathrm{CO}_{2}$ emissions, multivariate analysis, structural equations modeling. 


\section{INTRODUCTION AND OBJECTIVES}

Changes in coverage affect different soil properties (Jia et al., 2005), such as microbials (Krauss \& Allen, 2003), which act as early signs of degradation or soil improvement (Gichangi et al., 2016; Vallejo et al., 2012). These signs of variation are different between disturbed and undisturbed systems (Lagerlöf et al., 2014), which directly influence the stability of the ecosystem and soil fertility (Yang et al., 2010).

One of the main attributes to assess changes in soil properties caused by crops or changes in vegetation cover is the microbial biomass carbon (MBC) (Lopes et al., 2011). This responds quickly to the effect of soil disturbance or recovery (Rangel-Vasconcelos et al., 2015), since it maintains the living component of the soil's organic matter (SOM) (Araújo et al., 2013).

Fluctuations in the size of the MBC during the growing season is considered an important factor in controlling the carbon and nitrogen rotation of the soil (Yang et al., 2010). Likewise, the microbial biomass of the soil represents the lowest percentage of total nitrogen ( 1 to $5 \%$ ) of the soil, responsible for the labile reserve, the nutrient cycle and the decomposition of the SOM, being a good indicator of soil together with soil nitrogen (Fernandes et al., 2011; Jackson et al., 2003).

In this sense, the loss of organic matter and nutrients from the soil reduces the biomass and the microbial activity of the soil (Nunes et al., 2012); since the larger the $\mathrm{MBC}$, the greater the temporary immobilization of $\mathrm{C}, \mathrm{N}$ and other nutrients and then the lower the loss of nutrients from the soil/plant system (Moreira \& Malavolta, 2004; Wang et al., 2003). The transition from forest to pasture in the Amazon region has shown that MBC is reduced three years after pasture establishment but shows higher levels in old pastures with forest-like content (Cenciani et al., 2009).

On the other hand, it has been reported that tree species in a system have a different influence on soil C labile content (Silberman et al., 2015), thus influencing the structure and functionality of soil microbial communities (Anriquez et al., 2016; Silberman et al., 2016). Likewise, it is known that silvopastoral systems (SPS) are capable of improving the quality and function of the soil by reflecting increases in the $\mathrm{C}$ and $\mathrm{N}$ content of the soil microbial biomass, enzymatic activities and edaphic respiration (Cubillos et al., 2016;
Silberman et al., 2016; Vallejo et al., 2012). Therefore, the variability of microbial properties under different coverings in the Colombian Amazon was evaluated, hoping to find greater microbial activity of the soil in less intervened coverings such as the forest.

\section{MATERIALS AND METHODS}

\subsection{Study area}

The study was carried out in the Northwest of the Colombian Amazon, Southwest of Caquetá Department, between the municipalities of Morelia, Belén de los Andaquíes, Albania and San José del Fragua, cataloged in the life zone as a tropical rainforest. The climate is characterized by an average temperature of $24.1{ }^{\circ} \mathrm{C}$ in the period of highest precipitation (April-August), and $25^{\circ} \mathrm{C}$ in the dry season (November-March) with an annual rainfall between 2,500 and $4,000 \mathrm{~mm}$, its average relative humidity is $84 \%$ and the average height above sea level is $250 \mathrm{~m}$ (IGAC, 2014).

\subsection{Soil sampling}

Four constant land uses were studied in their vegetation cover: forest, forest plantation, silvopastoral system and pasture (Table 1). In each cover with a minimum area of one hectare, a diagonal transect was made in the direction of the slope. In this transect, three main sampling points with a diameter of $25 \mathrm{~m}$ were taken. At each point, a composite sample was made from four sub-samples at two depths (0-10 and $10-20 \mathrm{~cm}$, respectively). For the chemical analysis, the samples were dried at room temperature, then passed through a $2 \mathrm{~mm}$ sieve and stored in plastic bags. For the biochemical analysis, the samples were treated wet and were passed through a $2 \mathrm{~mm}$ sieve, stored in hermetic plastic bags and refrigerated at $4^{\circ} \mathrm{C}$ until further analysis.

\subsection{Edaphic properties}

To measure the water content of the soil, the ProCheck equipment adapted to a 5TE sensor was used. The $\mathrm{pH}$ was determined by the potentiometer in water. The organic carbon (OC) content of the soil was determined by the Walkley-Black method (Li et al., 2017).

The total nitrogen (TN) of the soil was measured by the micro-Kjeldahl method. The carbon of the MBC 
Table 1. Description of the coverages evaluated in the Colombian Amazon.

\begin{tabular}{ll}
$\begin{array}{l}\text { Coverage } \\
\text { Native } \\
\text { forest }\end{array}$ & $\begin{array}{l}\text { Conservation area with low human intervention, diversified vegetation coverage and in different } \\
\text { states of natural succession. }\end{array}$ \\
$\begin{array}{l}\text { Forest } \\
\text { plantation }\end{array}$ & $\begin{array}{l}\text { Area in recovery process, with vegetal cover of pasture in natural regeneration and 2-year-old } \\
\text { timber trees (Cariniana pyriformis, Cedrella odorata). }\end{array}$ \\
$\begin{array}{l}\text { Silvopastoral } \\
\text { system }\end{array}$ & $\begin{array}{l}\text { Area dedicated to bovine livestock farming, with diversified plant cover, divided into three strata: } \\
\text { high timber tree stratum (Gmelina arborea), middle stratum species for browsing (Tithonia } \\
\text { diversifolia) and stratum under the grass. }\end{array}$ \\
Pasture & Area dedicated to bovine livestock farming, with vegetal cover in monoculture of grasses. \\
\hline
\end{tabular}

and the nitrogen of the microbial biomass (MBN) were determined according to Vance et al. (1987) with extraction by $\mathrm{K}_{2} \mathrm{SO}_{4}$ of fumigated and non-fumigated soils with $\mathrm{CHCl}_{3}$.

Soil $\mathrm{CO}_{2}$ emissions were measured using the CIRAS-3 Portable Photosynthesis System infrared gas analyzer (PP Systems Inc., Amesbury, MA, USA) equipped with a soil respiration chamber (SRC-1). Registered $\mathrm{CO}_{2}$ emissions included autotrophic respiration of plant roots and heterotrophic respiration of soil organisms. The total readings of $\mathrm{CO}_{2}$ emissions from the soil shown by the CIRAS-3 were recorded and the results are presented as grams of carbon dioxide per square meter per second $\left(\mathrm{g} \mathrm{CO}_{2} \mathrm{~m}^{-2} \mathrm{~s}^{-1}\right)$.

\subsection{Statistical analysis}

A mixed linear model (MLM) was adjusted to predict the differences of soil microbial properties, and coverage and depth were included as fixed factors. The farm where the coverage was plotted and the plot considering the repetition within the coverage were included as random factors. The means comparisons were made using the Fisher LSD test $(p<0.05)$. The assumptions of normality and homogeneity of variance were evaluated through exploratory residue analysis. Likewise, a multivariate analysis was carried out to determine similarity between coverage-depths and to explore the relationship between variables through a principal components analysis (PCA), determining the similarity between coverage-depths by Monte Carlo test (1,000 permutations). Likewise, to determine the causal relationships between the multiple variables that interact and influence the microbial properties of the soil, they were adjusted in a structural equation model (SEM).
The MLM settings were carried out using the lme function of the nlme package (Pinheiro et al., 2015), the PCAs were developed in the package Ade4 (Dray \& Dufour, 2007) and the SEM was adjusted with the function $c f a$ of the SEM package (Fox, 2006). The visualization of the adjusted SEM was performed using the semPaths function of the semPlot package (Epskamp, 2014). All the statistical analyses carried out were developed using the $\mathrm{R}$ language version 3.4.0 (R Development Core Team, 2017) through the interface of the statistical software InfoStat (Di Rienzo et al., 2017).

\section{RESULTS AND DISCUSSION}

When analyzing the effect of coverage and depth on soil microbial properties, significant differences were found for soil moisture, $\mathrm{pH}, \mathrm{OC}$ and the $\mathrm{MBC} / \mathrm{OC}$ ratio $(p<0.05)$. For $\mathrm{MBC}$ and $\mathrm{dCO}_{2}$ differences were presented only for coverage and for TN, MBN and the $\mathrm{MBN} / \mathrm{TN}$ ratio in depth $(p<0.05)$. Likewise, differences were found for the interaction coverage $\times$ depth for the $\mathrm{C} / \mathrm{N}$ ratio $(p<0.05)$ (Table 2$)$.

The PCA for soil microbial properties explains $43.3 \%$ of the total variability of the data with the first two axes (Figure 1). Axis 1 associates the highest contents of $\mathrm{MBC}, \mathrm{MBC} / \mathrm{MBN}$ and $\mathrm{MBC} / \mathrm{OC}$ with the SPS coverage (Figure 1). Axis 2 expresses a gradient of higher $\mathrm{pH}$ and $\mathrm{TN}$, which are not clearly associated with a coverage (Figure 1). The results show a high coverage effect on soil microbial properties (p-value: 0.001) (Figure 1). There are also significant differences between depths for soil microbial properties (p-value: 0.001) (Figure 1). The depth $0-10 \mathrm{~cm}$ was characterized by having the highest contents of $\mathrm{C} / \mathrm{N}, \mathrm{MBN} / \mathrm{N}, \mathrm{MBN}, \mathrm{OC}, \mathrm{SM}$, $\mathrm{dCO}_{2}, \mathrm{MBC}, \mathrm{MBC} / \mathrm{MBN}$ and $\mathrm{MBC} / \mathrm{OC}$ (Figure 1). 
Table 2. Mean values $( \pm$ SE) of the edaphic properties, studied under different coverages in the Colombian Amazon.

\begin{tabular}{|c|c|c|c|c|c|c|c|c|c|c|c|}
\hline \multirow{3}{*}{ Variable } & \multicolumn{2}{|c|}{ Native forest } & \multicolumn{2}{|c|}{ Forest plantation } & \multicolumn{2}{|c|}{ Silvopastoral system } & \multicolumn{3}{|c|}{ Pasture } & \multirow{2}{*}{\multicolumn{2}{|c|}{ p-value }} \\
\hline & $0-10$ & $10-20$ & 0-10 & $10-20$ & $0-10$ & 10-20. & $0-1$ & 10 & $10-20$ & & \\
\hline & Average $\mathrm{SE}$ & Average SE. & Average $\mathrm{SE}$ & Average SE & Average $\mathrm{SE}$ & Average SE & Average & SE & Average SE & Coverage & Depth CobProf \\
\hline SM (\%) & $54.62 \pm 2.51$ & $47.73 \pm 0.91$ & $56.99 \pm 2.66$ & $45.61 \pm 2.17$ & $39.39 \pm 1.92$ & $34.69 \pm 0.94$ & $41.8 \pm$ & $=1.67$ & $34.57 \pm 1.15$ & $<0.0001$ & $<0.0001$ \\
\hline $\mathrm{pH}$ & $4.54 \pm 0.15$ & $4.49 \pm 0.12$ & $4.5 \pm 0.07$ & $4.64 \pm 0.09$ & $4.33 \pm 0.06$ & $4.56 \pm 0.06$ & $4.36 \pm$ & $=0.06$ & $4.64 \pm 0.06$ & 0.0107 & 0.0146 \\
\hline OC $(\%)$ & $2.9 \pm 0.15$ & $2.01 \pm 0.13$ & $3.54 \pm 0.2$ & $2.1 \pm 0.11$ & $3.55 \pm 0.11$ & $1.88 \pm 0.08$ & $3.37 \pm$ & $=0.11$ & $1.8 \pm 0.06$ & 0.0491 & $<0.0001$ \\
\hline TN (\%) & $0.74 \pm 0.01$ & $0.58 \pm 0.06$ & $0.72 \pm 0.03$ & $0.67 \pm 0.03$ & $0.69 \pm 0.03$ & $0.69 \pm 0.01$ & $0.73 \pm$ & $=0.02$ & $0.7 \pm 0.01$ & & $<0.0001$ \\
\hline
\end{tabular}

$\mathrm{MBC}(\mathrm{mg} / \mathrm{kg}) \quad 765.2 \pm 120.8 \quad 654 \pm 103 \quad 1002.5 \pm 286.9 \quad 1729.8 \pm 391.6 \quad 2376.9 \pm 566.92252 \pm 440 \quad 1707.1 \pm 311.3 \quad 1734.6 \pm 371.1 \quad 0.0191$

\begin{tabular}{|c|c|c|c|c|c|c|c|c|c|c|c|}
\hline MBN (mg/kg) & $39.18 \pm 9.22$ & $28.46 \pm 4.3$ & $34.45 \pm 6.81$ & $26.27 \pm 4.04$ & $42.55 \pm 6.34$ & $27.77 \pm 8.88$ & $56.77 \pm 8.03$ & $22.51 \pm 2.64$ & & 0.0077 & \\
\hline $\begin{array}{l}\mathrm{dCO}_{2} \\
\left(\mathrm{~g} \mathrm{CO}_{2} \mathrm{~m}^{-2} \mathrm{~s}^{-1}\right)\end{array}$ & $0.6 \pm 0.16$ & $0.66 \pm 0.3$ & $1.27 \pm 0.3$ & $1.12 \pm 0.31$ & $0.85 \pm 0.16$ & $0.35 \pm 0.09$ & $0.65 \pm 0.11$ & $0.58 \pm 0.13$ & 0.0085 & & \\
\hline $\mathrm{C} / \mathrm{N}$ & $3.95 \pm 0.23$ & $5.54 \pm 1.84$ & $5.37 \pm 0.58$ & $3.71 \pm 0.66$ & $6.24 \pm 0.74$ & $2.78 \pm 0.16$ & $4.93 \pm 0.35$ & $2.57 \pm 0.08$ & & 0.001 & 0.0044 \\
\hline
\end{tabular}

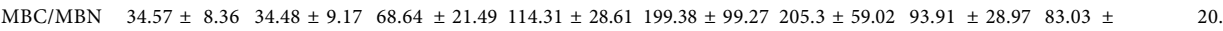

$\begin{array}{llllllllllllll}\mathrm{MBC} / \mathrm{OC} & 270.5 \pm 43.34 & 345 & \pm 62.1 & 281.94 \pm 74.35 & 777.06 \pm 140.2 & 769.5 \pm 198.1 & 1522 \pm 355.6 & 565.42 \pm 107.8 & 1108.8 \pm 267.5 & 0.0351 & 0.0343 & \\ \mathrm{MBN} / \mathrm{N} & 54.79 \pm 13.57 & 56.73 \pm 11.2 & 55.27 \pm 13.01 & 41.42 \pm 6.35 & 62 & \pm 8.23 & 41.2 \pm 12.63 & 78.53 \pm 10.42 & 31.77 \pm & \pm .5 & 0.0251 & \end{array}$

SE: standard error; SM: soil moisture; pH: acidity coefficient; OC: organic carbon; TN: total nitrogen; MBC: microbial biomass carbon; MBN: microbial biomass nitrogen; $\mathrm{dCO}_{2}$ : carbon dioxide delta; $\mathrm{C} / \mathrm{N}$ : ratio of carbon and nitrogen; $\mathrm{MBC} / \mathrm{MBN}$ : ratio of microbial biomass carbon and microbial biomass nitrogen; MBC/OC: ratio microbial biomass carbon and organic carbon; $\mathrm{MBN} / \mathrm{N}$ : ratio of microbial biomass nitrogen and nitrogen

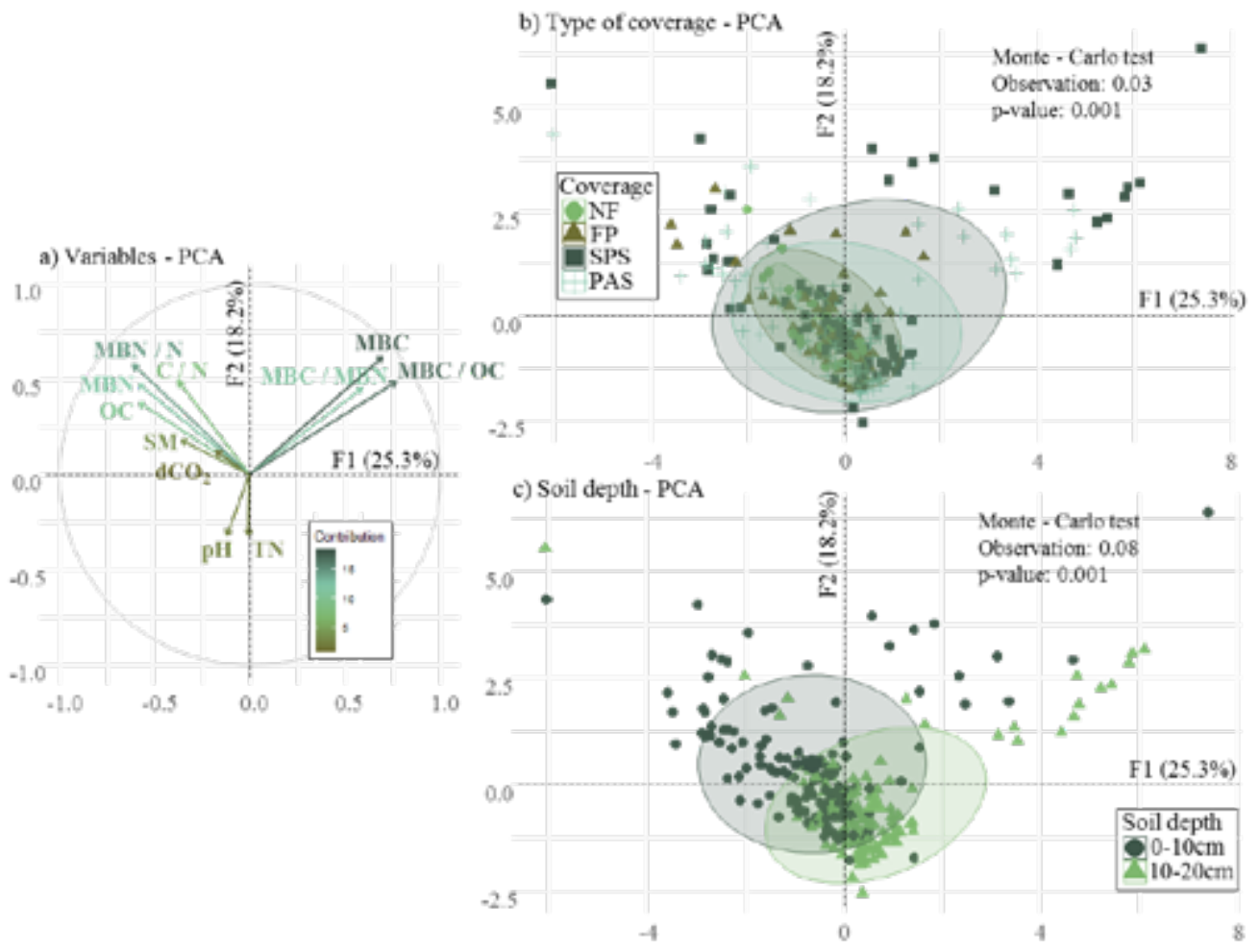

Figure 1. Projection in the factorial plane F1/F2 of the principal components' analysis of edaphic properties, and the samples points group depending on the type of coverage or the soil depth. a) Circle of correlations. b) Ordination of the coverage included in the sample on the factorial plane of a PCA. c) Ordination of the depths included in the sample on the factorial plane of an PCA. SM: soil humidity; $\mathrm{pH}$ : coefficient of acidity; OC: organic carbon; TN: total nitrogen; MBC: microbial biomass carbon; $\mathrm{MBN}$ : microbial biomass nitrogen; MBC/OC: relation of microbial biomass carbon and organic carbon; $\mathrm{MBN} / \mathrm{N}$ : relation of microbial biomass nitrogen and nitrogen; NF: native forest, FP: forest plantation; SPS: silvopastoral system; y PAS: pasture. 
There were differences in correlation trends between variables. OC was the soil variable that presented the highest correlation with the others, being positive with TN, $\mathrm{MBN}, \mathrm{dCO}_{2}$ and the $\mathrm{C} / \mathrm{N}$ and $\mathrm{MBN} / \mathrm{N}$ ratios $(p<0.05)$; and negative with $\mathrm{MBC} / \mathrm{OC}(p<0.05)$ (Table 3). The SEM analysis showed a good fit to the data (Figure 2), indicated by the non-significant value $\chi 2(p=0.85)$, high CFI (Confirmatory Fit Index 0.97), low RMSEA (Root Mean Square Error of Approximation 0.005 ) and low stability index 0.23 . The model suggests that the OC content strongly affects the activity of MBN, just as the concentration of TN affected at a low level. On the other hand, soil moisture content (SM) and organic carbon (OC) affected the carbon dioxide delta $\left(\mathrm{dCO}_{2}\right)$. However, the SEM shows a negative relationship between the $\mathrm{pH}$ and the $\mathrm{MBC}$.

Table 3. Correlation coefficients between edaphic properties under different coverages in the Colombian Amazon.

\begin{tabular}{|c|c|c|c|c|c|c|c|c|c|c|c|c|c|c|c|c|c|c|}
\hline Variables & SN & M & pH & O & & TI & & MB & & MB & & $\mathrm{dCO}_{2}$ & $\mathrm{C} / \mathrm{I}$ & & MBC/ & MBN & $\mathrm{MBC} / \mathrm{OC}$ & $\mathbf{M B N} / \mathbf{N}$ \\
\hline SM & 1 & & & & & & & & & & & & & & & & & \\
\hline $\mathrm{pH}$ & 0.01 & & 1 & & & & & & & & & & & & & & & \\
\hline OC & 0.39 & $<0.0001$ & $-0.16^{0.013}$ & 1 & & & & & & & & & & & & & & \\
\hline $\mathrm{TN}$ & 0.16 & 0.0102 & 0.04 & 0.13 & 0.037 & 1 & & & & & & & & & & & & \\
\hline MBC & -0.07 & & $-0.2 \quad 0.002$ & -0.07 & & -0.04 & & 1 & & & & & & & & & & \\
\hline MBN & 0.12 & & 0.02 & 0.29 & $<0.0001$ & 0.18 & 0.0043 & -0.02 & & 1 & & & & & & & & \\
\hline $\mathrm{dCO}_{2}$ & 0.33 & $<0.0001$ & -0.02 & 0.23 & 0.0003 & 0.07 & & 0.01 & & 0.05 & & 1 & & & & & & \\
\hline $\mathrm{C} / \mathrm{N}$ & 0.09 & & -0.02 & 0.45 & $<0.0001$ & -0.7 & $<0.0001$ & -0.05 & & 0.02 & & 0.02 & 1 & & & & & \\
\hline $\mathrm{MBC} / \mathrm{MBN}$ & -0.01 & & -0.12 & -0.08 & & -0.09 & & 0.61 & $<0.0001$ & -0.18 & 0.0049 & -0.02 & 0.01 & & 1 & & & \\
\hline $\mathrm{MBC} / \mathrm{OC}$ & -0.12 & 0.0683 & -0.11 & -0.25 & 0.0001 & -0.06 & & 0.9 & $<0.0001$ & -0.08 & & -0.06 & -0.13 & 0.0361 & 0.58 & $<0.0001$ & 1 & \\
\hline $\mathrm{MBN} / \mathrm{N}$ & 0.08 & & 0.01 & 0.27 & $<0.0001$ & -0.08 & & -0.02 & & 0.95 & $<0.0001$ & 0.02 & 0.23 & 0.0002 & -0.18 & 0.0042 & -0.07 & 1 \\
\hline
\end{tabular}

SM: soil moisture; $\mathrm{pH}$ : acidity coefficient; OC: organic carbon; TN: total nitrogen; MBC: the microbial biomass carbon; MBN: microbial biomass nitrogen; $\mathrm{dCO}_{2}$ : carbon dioxide delta; $\mathrm{C} / \mathrm{N}$ : ratio of carbon and nitrogen; $\mathrm{MBC} / \mathrm{MBN}$ : ratio of microbial biomass carbon and; $\mathrm{MBC} /$ OC: ratio of microbial biomass carbon and organic carbon; $\mathrm{MBN} / \mathrm{N}$ : ratio of microbial biomass nitrogen and nitrogen

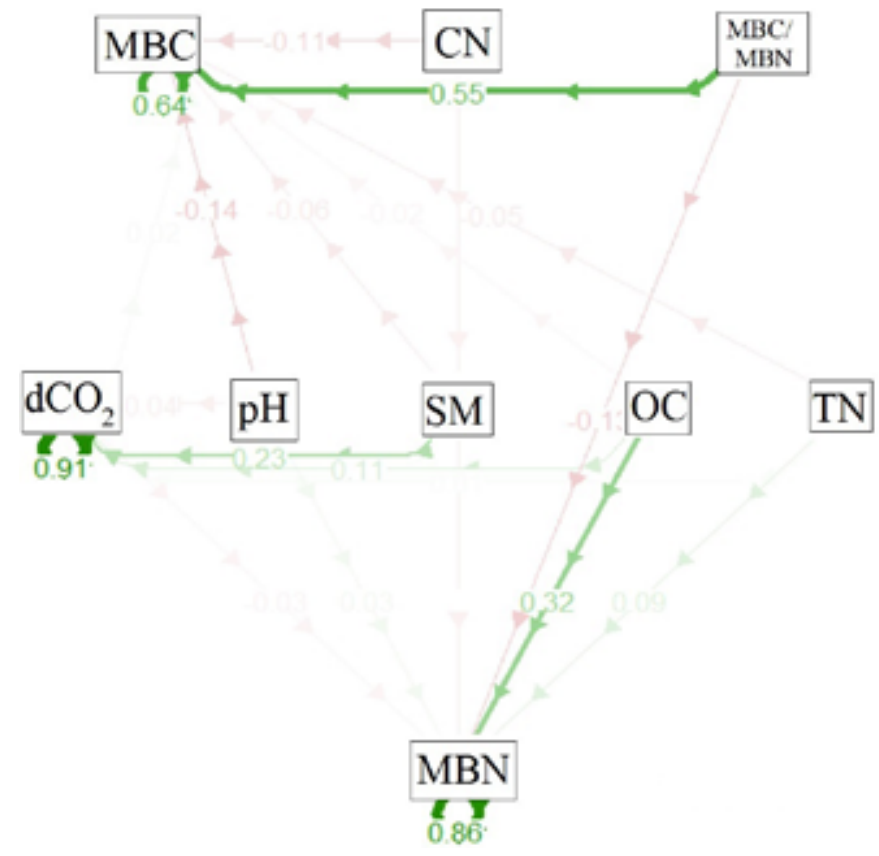

Figure 2. Direct and indirect effects between soil microbial properties with $M B N$ and MBC. MBN: microbial biomass nitrogen; MBC: microbial biomass carbon; NT: total nitrogen; OC: organic carbon; CN: carbon/nitrogen ratio; SM: soil moisture; $\mathrm{dCO}_{2}$ : carbon dioxide delta; $\mathrm{pH}$ : acidity coefficient; $\mathrm{MBC} / \mathrm{MBN}$ : ratio of microbial biomass carbon and microbial biomass nitrogen. The numbers in the vectors indicate significant standardized coefficients of relationship between variables. The green line indicates positive and the red line indicates negative effects. 
The OM decomposition is accelerated by the activity of the soil microorganisms (Spohn et al., 2016) which is measured by the MBC, in this way, the availability of OC depends on the characteristics of the soil, such as the depth, and not of coverage (Cubillos et al., 2016; Silva et al., 2012). Among coverages, SPS presented the highest MBC concentration (Table 1), possibly to the soil restoration that positively affected the microbial properties (Araújo et al., 2013), generating greater stability to the microorganisms (Anriquez et al., 2016) as well as the processes that they develop in the soil (Silva et al., 2012).

The high content of $\mathrm{MBC}$ is also associated with the radicular system of grasses that is abundant and remains active throughout the year (Nogueira et al., 2016) and with OM derived from animals (Toda et al., 2011). Therefore, land uses that guarantee the continuous entry of organic waste (Silva et al., 2012) will have a higher MBC (Nsabimana et al., 2004). By generally analyzing the relationships between different soil variables with microbial properties, associations were found with ecological functions capable of reflecting changes in land use (Jackson et al., 2003). Specifically, the important relationships are those presented between the OC and MBC, which explain the metabolic efficiency that exists under the coverage $\left(\mathrm{dCO}_{2}\right)$, that depends on the availability of substrate as organic matter.

Although in the present study there was no direct relationship between $\mathrm{OC}$ and $\mathrm{MBC}$, it is important to mention that this relationship is directly proportional, being susceptible to changes. The greater the MBC, the greater the temporary immobilization of $\mathrm{C}, \mathrm{N}$ and other nutrients, the lower the loss of nutrients from the soil-plant system (Moreira \& Malavolta, 2004; Wang et al., 2003), being analyzed in different studies (Oulbachir et al., 2009).

$\mathrm{MBC}$ is a very small fraction of the soil; however, it is very important since it refers to the fraction of $\mathrm{C}$ immobilized in microorganisms (Jia et al., 2005), being an easily mineralizable fraction (Rodrigues et al., 2015). Microbial growth depends mainly on greater availability of carbon in the soil, which is responsible for its variation (Rodrigues et al., 2015) because it regulates the energy flow and the nutrient cycle. On the other hand, when modifying the coverage, soil moisture changes that affect the microbial activity are presented
(Jia et al., 2005); in this way, a highly significant and positive correlation was found between soil moisture and OC (Table 3), which suggests that soil moisture has a significant influence on the accumulation or decomposition of organic matter (Jia et al., 2005) and therefore on microbial biomass, since it depends mainly on the organic carbon of the soil.

Among the various soil properties that influence the $\mathrm{MBC}$ of the soil, $\mathrm{pH}$ is an important component (Vallejo et al., 2010), especially in humid regions with acid soils (Tian et al., 2017), since most of the microorganisms are inhibited when the $\mathrm{pH}$ is less than 4.5 (Chen et al., 2015), which is considered a critical factor that determines the effect of the deposition of $\mathrm{N}$ in microorganisms (Geisseler \& Scow, 2014). In this study, it was found that the $\mathrm{pH}$ of the soil was negative with the MBC, due to the sensitivity of microbial activity to it (Vallejo et al., 2010). On the other hand, it was found that $\mathrm{OC}$ has a great influence on the activity of MBN and TN (Figure 2).

\section{CONCLUSIONS}

- The change in coverage affected the microbial properties of the soil, with the MBC being greater in the coverage with livestock activity such as silvopastoral system and pasture.

- The soil depth 0-10 cm exhibited higher microbial activity, as well as higher soil moisture, organic carbon and carbon dioxide delta.

- The organic carbon content in the soil affected edaphic properties, such as NT, $\mathrm{MBN}, \mathrm{dCO}_{2}, \mathrm{C} / \mathrm{N}, \mathrm{MBN} / \mathrm{N}$ and $\mathrm{MBC} / \mathrm{OC}$.

\section{ACKNOWLEDGEMENTS}

We are thankful to the Amazon Sustainable Landscapes Program, guided by International Center for Tropical Agriculture (CIAT) through a partnership with the University of Amazonia C-003-15-CIAT. This program is part of the International Climate Initiative (IKI) led by the Federal Ministry for the Environment, Nature Conservation, Building and Nuclear Safety (BMU) in Germany. 


\section{SUBMISSION STATUS}

Received: 17 Oct., 2017

Accepted: 24 Nov., 2018

\section{CORRESPONDENCE TO}

\section{Juan Carlos Suárez Salazar}

Universidad de la Amazonia, Av. Circunvalar, s/n, CEP 180002, Florencia, Colômbia

e-mail: juansuarez1@gmail.com

\section{REFERENCES}

Anriquez A, Arias S, Silberman JE, Domínguez-Núñez JA, Kunst CG, Albanesi AS. Sistema silvopastoril con diferentes coberturas arbóreas habilitado por rolado de baja intensidad. Impacto en glomalinas y fracciones de carbono del suelo. Ciencia del Suelo 2016 [cited 2019 May 22]; 34(1): 33-41. Available from: https://bit.ly/2YBXbI6

Araújo ASF, Cesarz S, Leite LFC, Borges CD, Tsai SM, Eisenhauer N. Soil microbial properties and temporal stability in degraded and restored lands of Northeast Brazil. Soil Biology and Biochemistry 2013; 66: 175-181. 10.1016/j.soilbio.2013.07.013

Cenciani K, Lambais MR, Cerri CC, Azevedo LCB, Feigl BJ. Bacteria diversity and microbial biomass in forest, pasture and fallow soils in the southwestern amazon basin. Revista Brasileira de Ciência do Solo 2009; 33: 907-916. 10.1590/S0100-06832009000400015

Chen D, Mi J, Chu P, Cheng J, Zhang L, Pan Q et al. Patterns and drivers of soil microbial communities along a precipitation gradient on the Mongolian plateau. Landscape Ecology 2015; 30(9): 1669-1682. 10.1007/ s10980-014-9996-Z

Cubillos AM, Vallejo VE, Arbeli Z, Terán W, Dick RP, Molina $\mathrm{CH}$ et al. Effect of the conversion of conventional pasture to intensive silvopastoral systems on edaphic bacterial and ammonia oxidizer communities in Colombia. European Journal of Soil Biology 2016; 72: 42-50. 10.1016/j.ejsobi.2015.12.003

Di Rienzo JA, Casanoves F, Balzarini M, Gonzalez L, Tablada M, Robledo CW. InfoStat - Software Estadístico. Version 2017 [software]. 2017 [cited 2017 Jul. 27]. Available from: https://bit.ly/2VZ2Pr8

Dray S, Dufour AB. The ade4 package: implementing the duality diagram for ecologists. Journal of Statistical Software 2007; 22(4): 1-20. 10.18637/jss.v022.i04

Epskamp, S. semPlot: Path diagrams and visual analysis of various SEM packages' output. Version 1.0.0 [software]. 2014 [cited 2019 May 22]. Available from: https://bit.ly/2YJMWl2
Fernandes MM, Moura MR, Lima RP, Nóbrega RSA. Carbono e nitrogênio da biomassa microbiana e do solo de uma área degradada revegetada com tamboril no sul do Piauí. Revista Científica Eletrônica de Engenharia Florestal 2011 [cited 2019 May 22]; 18(1): 1-11. Available from: https://bit.ly/2whb3eI

Fox J. Teacher's corner: structural equation modeling with the sem package in R. Structural Equation Modeling 2006; 13(3): 465-486. 10.1207/s15328007sem1303_7

Geisseler D, Scow KM. Long-term effects of mineral fertilizers on soil microorganisms: a review. Soil Biology and Biochemistry 2014; 75: 54-63. 10.1016/j. soilbio.2014.03.023

Gichangi EM, Njarui DMG, Gatheru MJ, Magiroi KWN, Ghimire SR. Effects of brachiaria grasses on soil microbial biomass carbon, nitrogen and phosphorus in soils of the semi arid tropics of Kenya. Tropical and Subtropical Agroecosystems 2016 [cited 2019 May 22]; 19(2): 193-203. Available from: https://bit.ly/30LXGRY

Instituto Geográfico Agustín Codazzi - Igac. Estudio general de suelos y zonificación de tierras: Departamento de Caquetá. Bogotá: IGAC; 2014.

Jackson LE, Calderon FJ, Steenwerth K, Scow K, Rolston DE. Responses of soil microbial process and community structure to tillage events and implications for soil quality. Geoderma 2003; 114(3): 305-317. 10.1016/S00167061(03)00046-6

Jia GM, Cao J, Wang C, Wang G. Microbial biomass and nutrients in soil at the different stages of secondary forest succession in Ziwulin, northwest China. Forest Ecology and Management 2005; 217(1): 117-125. 10.1016/j. foreco.2005.05.055

Krauss KW, Allen JA. Factors influencing the regeneration of the mangrove Bruguiera gymnorrhiza (L.). Lamk. on a tropical Pacific island. Forest Ecology and Management 2003; 176(1): 49-60. 10.1016/S0378-1127(02)00219-0

Lagerlöf J, Adolfsson L, Börjesson G, Ehlers K, Vinyoles GP, Sundh I. Land-use intensification and agroforestry in the Kenyan highland: Impacts on soil microbial community composition and functional capacity. Applied Soil Ecology 2014; 82: 93-99. 10.1016/j.apsoil.2014.05.015

Li J, He N, Xu L, Chai H, Liu Y, Wang D et al. Asymmetric responses of soil heterotrophic respiration to rising and decreasing temperatures. Soil Biology and Biochemistry 2017; 106: 18-27. 10.1016/j.soilbio.2016.12.002

Lopes ELN, Fernandes AR, Ruivo MLP, Cattanio JH, Souza GF. Microbial biomass and soil chemical properties under different land use systems in northeastern Pará. Revista Brasileira de Ciência do Solo 2011; 35(4): 1127-1139. 10.1590/S0100-06832011000400006

Moreira A, Malavolta E. Dinâmica da matéria orgânica e da biomassa microbiana em solo submetido a diferentes sistemas de manejo na Amazônia Ocidental. Pesquisa 
Agropecuária Brasileira 2004; 39(11): 1103-1110. 10.1590/ S0100-204X2004001100008

Nogueira LR, Silva CF, Pereira MG, Gaia-Gomes JH, Silva EMR. Biological properties and organic matter dynamics of soil in pasture and natural regeneration areas in the Atlantic forest biome. Revista Brasileira de Ciência do Solo 2016; 40: e0150366. 10.1590/18069657rbcs20150366

Nsabimana D, Haynes RJ, Wallis FM. Size, activity and catabolic diversity of the soil microbial biomass as affected by land use. Applied Soil Ecology 2004; 26(2): 81-92. 10.1016/j.apsoil.2003.12.005

Nunes JS, Araújo ASF, Nunes LAPL, Lima LM, Carneiro $\mathrm{RFV}$, Salviano AAC et al. Impact of land and degradation on soil microbial biomass and activity in Northeast Brazil. Pedosphere 2012; 22(1): 88-95. 10.1016/S10020160(11)60194-X

Oulbachir K, Dellal A, Bekki A. Les variations de la biomasse microbienne etudiée sous des environnementales différentes dans quatre sols superposés séparés deux à deux par une croûte calcaire. European Journal of Scientific Research 2009; 36(3): 407-417.

Pinheiro J, Bates D, DebRoy S, Sarkar D, Heisterkamp S, Van Willigen $B$ et al. nlme: linear and nonlinear mixed effects models. 2015 [cited 2017 Jul. 21]. Available from: https://bit.ly/2Hyww9F

$\mathrm{R}$ Development Core Team. The R Project for Statistical Computing [software]. 2017 [cited 2018 Apr. 22]. Available from: https://bit.ly/19WExR5

Rangel-Vasconcelos LGT, Zarin DJ, Oliveira FA, Vasconcelos SS, Carvalho CJR, Santos MMLS. Effect of water availability on soil microbial biomass in secondary forest in eastern Amazonia. Revista Brasileira de Ciência do Solo 2015; 39(2): 377-384. 10.1590/01000683rbcs20140135

Rodrigues RC, Araújo RA, Costa CS, Lima AJT, Oliveira ME, Cutrim JAA Jr et al. Soil microbial biomass in an agroforestry system of Northeast Brazil. Tropical Grasslands 2015; 3(1): 41-48. 10.17138/tgft(3)41-48

Silberman JE, Anriquez AL, Domínguez-Nuñez JA, Kunst CG, Albanesi AS. La cobertura arbórea en un sistema silvopastoril del chaco y su contribución diferencial al suelo. Ciencia del Suelo 2015 [cited 2019 May 22]; 33(1): 19-29. Available from: https://bit.ly/30GBEQs

Silberman JE, Albanesi A, Grasso D. Manejo de bosques con ganadería integrada: impacto en las comunidades microbianas del suelo. Ciencia del Suelo 2016 [cited
2019 May 23]; 34(2): 211-219. Available from: https:// bit.ly/2JABswH

Silva DKA, Freitas NO, Sousa RG, Silva FSB, Araújo ASF, Maia LC. Soil microbial biomass and activity under natural and regenerated forests and conventional sugarcane plantations in Brazil. Geoderma 2012; 189: 257-261. 10.1016/j.geoderma.2012.06.014

Spohn M, Klaus K, Wanek W, Richter A. Microbial carbon use efficiency and biomass turnover times depending on soil depth: implications for carbon cycling. Soil Biology and Biochemistry 2016; 96: 74-81. 10.1016/j.soilbio. 2016.01.016

Tian D, Jiang L, Ma S, Fang W, Schmid B, Xu L et al. Effects of nitrogen deposition on soil microbial communities in temperate and subtropical forests in China. Science of The Total Environment 2017; 607-608(31): 1367-1375. 10.1016/j.scitotenv.2017.06.057

Toda FE, Vasques T, Araújo FF. Biomassa microbiana e sua correlação com a fertilidade de solos em diferentes sistemas de cultivo. Colloquium Agrariae 2011; 6(2): 1-7. 10.5747/ca.2010.v06.n2.a051

Vallejo V, Arbeli Z, Terán W, Lorenz N, Dick RP, Roldan F. Effect of land management and Prosopis juliflora (Sw.) DC trees on soil microbial community and enzymatic activities in silvopastoral systems of Colombia. Agriculture, Ecosystems \& Environment 2012; 150: 139-148. 10.1016/j. agee.2012.01.022

Vallejo VE, Roldan F, Dick RP. Soil enzymatic activities and microbial biomass in an integrated agroforestry chronosequence compared to monoculture and a native forest of Colombia. Biology and Fertility of Soils 2010; 46(6): 577-587. 10.1007/s00374-010-0466-8

Vance ED, Brookes PC, Jenkinson DS. An extraction method for measuring soil microbial biomass. Soil Biology \& Biochemistry 1987; 19(6): 703-707. 10.1016/00380717(87)90052-6

Wang WJ, Dalal RC, Moody PW, Smith CJ. Relationships of soil respiration to microbial biomass, substrate availability and clay content. Soil Biology and Biochemistry 2003; 35(2): 273-284. 10.1016/S0038-0717(02)00274-2

Yang K, Zhu J, Zhang M, Yan Q, Sun OJ. Soil microbial biomass carbon and nitrogen in forest ecosystems of northeast China: a comparison between natural secondary forest and larch plantation. Journal of Plant Ecology 2010; 3(3): 175-182. 10.1093/jpe/rtq022 